DE GRUYTER

JOURNAL OF BASIC AND CLINICAL PHYSIOLOGY AND PHARMACOLOGY

EOTOR-IN-CHIEF

Michat Horowits 
Volume 30 (2019): Issue 6 (Nov 2019): Conference Special Issue: 2nd International Graduate Student Conference on Pharmaceutical Sciences (IGSCPS) \& 2019 International Joint Symposium of the 8th Asia Pacific Pharmacy Education Network and the 2nd Halal Pharmaceuticals and Cosmetics (APPEN-HPC) / Guest Editors: Elida Zairina \& Chrismawan Ardianto in Journal of Basic and Clinical Physiology and Pharmacology

- REVIEWS

- Pharmacist contributions in the treatment of diabetes mellitus in Southeast Asia: a narrative review

Ayu Wulan Dwiputri, Liza Pristianty, and Andi Hermansyah

Article Category: Review Article

Article Number: 20190322

Published online: 23 Jan 2020

ABSTRACT

Background

The growing burden of diabetes mellitus (DM) in Southeast Asia puts pharmacists in the ideal position to provide management of DM. This na... Show More

- The implementation of a chronic disease management program (Prolanis) in Indonesia: a literature review

Sesty Rachmawati, Hanni Prihhastuti-Puspitasari, and Elida Zairina

Article Category: Review Article

Article Number: 20190350

Published online: 20 Dec 2019

ABSTRACT

Background

The Chronic Disease Management Program or Program Pengelolaan Penyakit Kronis (Prolanis) is a program initiated by the Social Insurance A... Show More

- ORIGINAL ARTICLES

- Quercetin attenuates acute predator stress exposure-evoked innate fear and behavioral perturbation

Putri Anggreini, Chrismawan Ardianto, Mahardian Rahmadi, and Junaidi Khotib

Article Category: Research Article

Article Number: 20190242

Published online: 28 Nov 2019

ABSTRACT

Background

Oxidative stress plays a pivotal role in the pathophysiology and pathogenesis of mental diseases, such as depression or anxiety. Psychol... Show More

- Evaluating current practices and policies in the use of injectable medicines for treating myalgia in a primary care center in Pamekasan, Indonesia

Eko Prasetio, Wahyu Utami, Zulhabri Othman, Ari Wardani, Abdul Rahem, and Andi Hermansyah

Article Category: Research Article

Article Number: 20190328

Published online: 07 Feb 2020

ABSTRACT

Background

Myalgia in patients can be associated with a large array of conditions, including injuries, infections and inflammations.

Treatment for m... Show More

- The contemporary role and potential of pharmacist contribution for community health using social media

Andi Hermansyah, Anila Impian Sukorini, Fadli Asmani, Kandi Aryani Suwito, and Titik Puji Rahayu

Article Category: Research Article

Article Number: 20190329

Published online: 04 Dec 2019

ABSTRACT

Background

Social media (SM) is everywhere, and it affects all aspects of life, including health care. This study aimed to identify

pharmacist activ... Show More

PDF FREE ACCESS

- Evaluation of rational drug use based on World Health Organization prescribing indicators in a primary care center in Pamekasan East Java, Indonesia

Eko Prasetio, Wahyu Utami, Zulhabri Othman, Ari Wardani, Abdul Rahem, and Andi Hermansyah

Article Category: Research Article

Article Number: 20190326

Published online: 07 Feb 2020

ABSTRACT

Background 
The Government of Indonesia has put in place many interventions for rationalizing drug use at all levels of the health services including... Show More

- The prescription patterns of second-generation antipsychotics in schizophrenia outpatient setting

Julaeha Julaeha, Umi Athiyah, and Andi Hermansyah

Article Category: Research Article

Article Number: 20190289

Published online: 14 Dec 2019

ABSTRACT

Background

Schizophrenia is a chronic disorder that requires long-term treatment to achieve symptom remission and quality of life improvement. Antip... Show More

Factors affecting community pharmacist's service for women with chronic diseases during pregnancy and breastfeeding: application of the Health Belief Model

Septi Anggraini, Wahyu Utami, and Elida Zairina

Article Category: Research Article

Article Number: 20190347

Published online: 19 Dec 2019

ABSTRACT

Background

Pharmacists are known as health care professionals who are responsible for the safety and efficacy of medicine to achieve optimal therape... Show More

Overview of therapeutic changes in antiepileptic drugs in adult patients

Dinda M.N. Ratri, Mahardian Rahmadi, Wardah R. Islamiyah, and Nur Faridah Harum

Article Category: Research Article

Article Number: 20190346

Published online: 11 Jan 2020

ABSTRACT

Background

Previous studies suggest a highly variable response of antiepileptic drugs (AEDs). This may be because the response to AEDs has been chan... Show More

- Exploration of barriers affecting job satisfaction among community pharmacists

Muhammad Khalid Rijaluddin, Wahyu Utami, Zulhabri Othman, Hanni Prihhastuti Puspitasari, Abdul Rahem, Anila Impian Sukorini, and Andi Hermansyah

Article Category: Research Article

Article Number: 20190325

Published online: 13 Jan 2020

ABSTRACT

Background

Understanding job satisfaction among community pharmacists is important as it may affect roles and performance.

Several barriers in pract... Show More

- Patients' characteristics and their adherence to insulin therapy

Yunti Fitriani, Liza Pristianty, and Andi Hermansyah

Article Category: Research Article

Article Number: 20190330

Published online: 15 Jan 2020

ABSTRACT

Background

The prevalence of type 2 diabetes mellitus (DMT2) in Indonesia increased significantly from 6.9\% (2013) to 8.5\% (2018), putting Indonesia... Show More

- Correlation of chemotherapy costs with quality of life in nasopharyngeal cancer patients

Achmad Chusnu Romdhoni, Riskha Aulia, Ririn Prasetyo Utaminingtyas, Suharjono, and Christopher Paul Alderman

Article Category: Research Article

Article Number: 20190238

Published online: 23 Jan 2020

ABSTRACT

Background

Nasopharyngeal cancer (NPC) is the most common neck/head cancer occurring in Indonesia and is the fourth most malignant after breast ca... Show More

- Impact of educational preeclampsia prevention booklet on knowledge and adherence to low dose aspirin among pregnant women with high risk for preeclampsia

Rella Indah Karunia, Anita Purnamayanti, and Fransiscus O.H. Prasetyadi

Article Category: Research Article

Article Number: 20190299 
Published online: 13 Jan 2020

ABSTRACT

Background

Postpartum bleeding and pregnancy induced hypertension - including preeclampsia - remain to be a great cause of maternal mortality. The u... Show More

- Translation, cultural adaptation, and validation of the quality of well being self-administered questionnaire in general population in Indonesia

Tri Murti Andayani, Susi Ari Kristina, and Dwi Endarti

Article Category: Research Article

Article Number: 20190268

Published online: 20 Dec 2019

ABSTRACT

Background

The quality of well being self-administered (QWB-SA) questionnaire is one of the generic instruments which can be used to measure the ut... Show More

- Knowledge, attitude, and practice of pharmacists towards management of hypertension in primary care centers

I Nyoman Wijaya, Umi Athiyah, Fasich, and Andi Hermansyah

Article Category: Research Article

Article Number: 20190319

Published online: 11 Jan 2020

ABSTRACT

Background

Hypertension is one of the major health problems of the world and one of the most important causes of death in Indonesia. Complication du... Show More

- Medication adherence in diabetes mellitus patients at Tanjung Karang Primary Health Care Center, Mataram

Mahacita Andanalusia, Umi Athiyah, and Yunita Nita

Article Category: Research Article

Article Number: 20190287

Published online: 18 Dec 2019

ABSTRACT

Background

The prevalence of diabetes mellitus continues to increase every year, including in Indonesia. To prevent complications of diabetes mellit... Show More

$\circ \quad$ Decreasing angiogenesis vasa vasorum through Lp-PLA $\mathrm{A}_{2}$ and $\mathrm{H}_{2} \mathrm{O}_{2}$ inhibition by PSP from Ganoderma lucidum in atherosclerosis: in vivodiabetes mellitus type 2

Titin Andri Wihastuti, Reyhan Amiruddin, Fibe Yulinda Cesa, Amalia Istiqamah Alkaf, Meddy Setiawan, and Teuku Heriansyah

Article Category: Research Article

Article Number: 20190349

Published online: 07 Feb 2020

ABSTRACT

Background

Type 2 diabetes mellitus (T2DM) is a major risk factor of atherosclerosis. Hyperglycemia in T2DM causes advanced formation of glycation e... Show More

- Antiaggregation effect of clopidogrel in coronary heart disease patients using omeprazole

Dian Hasiannami Boru Munthe, Siti Sjamsiah Sargo, and Mohammad Yogiarto

Article Category: Research Article

Article Number: 20190266

Published online: 25 Jan 2020

ABSTRACT

Background

Antiplatelet agents used in coronary heart disease (CHD) cause gastrointestinal side effects. Omeprazole can prevent and cure these anti... Show More

- The effect of curcuma (Curcuma xanthorrizha roxb.) extract as an adjuvant of captopril therapy on cardiac histopathology of male mice (Mus musculus) with hypertension

Nursela Hijriani, Lilik Yusetyani, and Didik Hasmono

Article Category: Research Article

Article Number: 20190280

Published online: 11 Jan 2020

ABSTRACT

Background

Hypertension is a cardiovascular disease which has become a major health problem in Indonesia. Left ventricle

hypertrophy is one of the... Show More 
Coenzyme Q10 nanostructured lipid carriers as an inducer of the skin fibroblast cell and its irritability test in a mice $\underline{\text { model }}$

Fenita Shoviantari, Tristiana Erawati, and Widji Soeratri

Article Category: Research Article

Article Number: 20190320

Published online: 20 Dec 2019

ABSTRACT

Background

Coenzyme Q10 is a fat-soluble antioxidant that can help to prevent collagen and elastin damage and avoid wrinkles.

Coenzyme Q10 has sever... Show More

- Medical problems in patients with chronic kidney disease undergoing hemodialysis and their therapy

Budi Suprapti, Wenny Putri Nilamsari, Rachmania, Widodo, and Chris Alderman

Article Category: Research Article

Article Number: 20190250

Published online: 20 Nov 2019

ABSTRACT

Background

It was reported that hemodialysis (HD) with either a new or reused dialyzer raises medical problems that require therapeutic regimens. T... Show More

ADMET properties of novel 5-O-benzoylpinostrobin derivatives

Mohammad Rizki Fadhil Pratama, Hadi Poerwono, and Siswandono Siswodiharjo

Article Category: Research Article

Article Number: 20190251

Published online: 18 Dec 2019

ABSTRACT

Background

Prediction of the properties of absorption, distribution, metabolism, excretion, and toxicity (ADMET) from a compound is essential, espe... Show More

- Development of nonalcoholic fatty liver disease model by high-fat diet in rats

Hijrawati Ayu Wardani, Mahardian Rahmadi, Chrismawan Ardianto, Santhra Segaran Balan, Norshafarina Shari

Kamaruddin, and Junaidi Khotib

Article Category: Research Article

Article Number: 20190258

Published online: 25 Nov 2019

ABSTRACT

Background

Nonalcoholic fatty liver disease (NAFLD) is indicated by liver steatosis without excessive alcohol use or other liver disease. Several s... Show More

Molecular docking of novel 5-O-benzoylpinostrobin derivatives as wild type and L858R/T790M/V948R mutant EGFR inhibitor

Mohammad Rizki Fadhil Pratama, Hadi Poerwono, and Siswandono Siswodihardjo

Article Category: Research Article

Article Number: 20190301

Published online: 19 Dec 2019

ABSTRACT

Background

Previous studies have shown that 5-O-benzoylpinostrobin derivatives is a potential anti-breast cancer, with the highest potential being t... Show More

- The relationship between the level of education and accuracy of insulin injection techniques in DM patients with measurement of $\mathrm{HbA}_{1 c}$ values

Anisyah Achmad, Fatchur Rohmi Latifatus Sholihah, Wanda Fenny Oktavianti, and Laksmi Sasiarini

Article Category: Research Article

Article Number: 20190303

Published online: 25 Jan 2020

ABSTRACT

Background

Insulin therapy is a major part of diabetes treatment. The insulin injection technique must be done accurately and needs a professional p... Show More

- The effect of premixed insulin to blood glucose concentration in patients with type 2 diabetes mellitus

Arina D. Puspitasari, Hayu Kusuma, Dinda M.N. Ratri, Cahyo Wibisono, and Budi Suprapti

Article Category: Research Article

Article Number: 20190342

Published online: 11 Jan 2020 
ABSTRACT

Background

One of the therapies used to treat type 2 diabetes mellitus (T2DM) disease is combination insulin which consists of rapid-acting insulin... Show More

- Intravenous insulin therapy in diabetes mellitus with hyperglycemic crisis and intercurrent illness

Budi Suprapti, Fairuza Syarfina, Chrismawan Ardianto, and Cahyo Wibisono

Article Category: Research Article

Article Number: 20190337

Published online: 11 Jan 2020

ABSTRACT

Background

Hyperglycemic crisis is one of the complications of diabetes mellitus, which is common in hospitalized diabetic patient with intercurrent... Show More

- Adherence behavior assessment of oral antidiabetic medication use: a study of patient decisions in long-term disease management in primary health care centers in Surabaya

Lisa Aditama, Umi Athiyah, Wahyu Utami, and Abdul Rahem

Article Category: Research Article

Article Number: 20190257

Published online: 18 Jan 2020

ABSTRACT

Background

Adherence to medication has an important role in the long-term management of diabetes. The Indonesian

Endocrinologist Association found... Show More

- Evaluation to the chemotherapy use in patients with diffuse large B-cell lymphoma

Dirani Dirani, Suharjono, Made Sedana, Siti Wahyuni, Chrismawan Ardianto, and Chris Alderman

Article Category: Research Article

Article Number: 20190336

Published online: 13 Jan 2020

ABSTRACT

Background

Non-Hodgkin lymphoma (NHL) is a large group of primary malignancies of solid lymphoid tissue. Diffuse large B-cell lymphoma (DLBCL) is th... Show More

- Analysis of the use and cost of stress ulcer prophylaxis for surgical inpatients

Dhani Wijaya, Elfri Padolo, Chrismawan Ardianto, Sumarno, Fendy Matulatan, Chris Alderman, and Suharjono

Article Category: Research Article

Article Number: 20190306

Published online: 11 Jan 2020

ABSTRACT

Background

Stress ulcer is a superficial and asymptomatic lesion and causes bleeding. As many as $50 \%$ of death cases are reported as the result of st... Show More

- Antineuroinflammation activity of $n$-butanol fraction of Marsilea crenata Presl. in microglia HMC3 cell line

Burhan Ma'arif, Denis Mery Mirza, Mu’akibatul Hasanah, Hening Laswati, and Mangestuti Agil

Article Category: Research Article

Article Number: 20190255

Published online: 22 Jan 2020

ABSTRACT

Background

Neuroinflammation is one of the main causes of neurodegenerative events. Phytoestrogen is a group compounds that have an estrogen-like s... Show More

- The enhancement of Arg1 and activated ER $\beta$ expression in microglia HMC3 by induction of $96 \%$ ethanol extract of Marsilea crenata Presl. leaves

Burhan Ma'arif, Mangestuti Agil, and Hening Laswati

Article Category: Research Article

Article Number: 20190284

Published online: 25 Jan 2020

ABSTRACT

Background

Phytoestrogens have a high potential to overcome the neuroinflammation caused by estrogen deficiency. Marsilea crenata Presl. is a plant k... Show More

- Ternary solid dispersion to improve solubility and dissolution of meloxicam

Dwi Setyawan, Meivita Yusmala Dewi, and Dewi Isadiartuti

Article Category: Research Article 
Article Number: 20190244

Published online: 14 Dec 2019

ABSTRACT

Background

Meloxicam (MLX) is a potent non-steroidal anti-inflammatory drug with poor solubility. Solid dispersion (SD) is an

effective formulation... Show More

- Improving solubility and dissolution of meloxicam by solid dispersion using hydroxypropyl methylcellulose $29103 \mathrm{cps}$ and nicotinamide

Ana Fathanah, Dwi Setyawan, and Retno Sari

Article Category: Research Article

Article Number: 20190249

Published online: 14 Dec 2019

ABSTRACT

Background

Solid dispersion (SD) represents a good method for enhancing the solubility of poorly water-soluble drugs. Meloxicam (MLX), a nonsteroid... Show More

O $\mathrm{o}$-Hydroxycinnamic derivatives as prospective anti-platelet candidates: in silico pharmacokinetic screening and evaluation of their binding sites on $\mathrm{COX}-1$ and $\mathrm{P}_{2} \mathrm{Y}_{12}$ receptors

Kholis Amalia Nofianti and Juni Ekowati

Article Category: Research Article

Article Number: 20190327

Published online: 19 Dec 2019

ABSTRACT

Background

The high prevalence of thrombotic abnormalities has become a major concern in the health sector. This is triggered by uncontrolled platel... Show More

$\circ \quad$ The change of proinflammatory cytokine tumor necrosis factor $\alpha$ level in the use of meloxicam in rat model of osteoarthritis

Junaidi Khotib, Naning Windi Utami, Maria Apriliani Gani, and Chrismawan Ardianto

Article Category: Research Article

Article Number: 20190331

Published online: 14 Dec 2019

ABSTRACT

Background

Osteoarthritis $(\mathrm{OA})$ is a chronic disease in the joints. One of the proinflammatory cytokines that is thought to have a major role in the i... Show More

- Attenuation of IL-1ß on the use of glucosamine as an adjuvant in meloxicam treatment in rat models with osteoarthritis

Junaidi Khotib, Asri Putri Pratiwi, Chrismawan Ardianto, and Mahardian Rahmadi

Article Category: Research Article

Article Number: 20190332

Published online: 11 Jan 2020

ABSTRACT

Background

Osteoarthritis $(\mathrm{OA})$ is the most prevalent joint disease and a common cause of joint pain, functional loss, and disability. The severity o... Show More

- Analysis of effectiveness and drug related problems of pain reliever for knee osteoarthritis: weighing clinical risk and benefit

Junaidi Khotib, Henny Utami Setiawan, Ahmad Dzulfikri Nurhan, Erreza Rahadiansyah, Chrismawan

Ardianto, and Mahardian Rahmadi

Article Category: Research Article

Article Number: 20190338

Published online: 11 Feb 2020

ABSTRACT

Background

Osteoarthritis (OA) is a chronic degenerative joint disease, characterized by physiological disorders, such as cartilage degradation, bon... Show More

- Comparison of antibiotic prescriptions in adults and children with upper respiratory tract infections in Bangka Tengah primary health care centers

Pratama Novan Y. I., Avianto Primadi, Mahfudz, and Suharjono

Article Category: Research Article

Article Number: 20190248

Published online: 11 Jan 2020 
ABSTRACT

Background

Inappropriate antibiotic therapy is accelerating the development of antimicrobial resistance (AMR). Upper respiratory tract infections (... Show More

- Profile of sociodemographics, sources of infection, antiretrovirals and CD4 counts on HIV/AIDS outpatients in Turen Primary Health Centre, Indonesia

Ellyvina S. Dhini, Antonius Adji P. Setiadi, and Yosi I. Wibowo

Article Category: Research Article

Article Number: 20190259

Published online: 19 Dec 2019

ABSTRACT

Background

The profile of patients with HIV/AIDS is required to develop appropriate HIV/AIDS prevention and treatment programs in Indonesia. Turen... Show More

- Synergistic anti-hepatitis C virus activity of Ruta angustifolia extract with NS3 protein inhibitor

Tutik Sri Wahyuni, Humairoh Mahfud, Adita Ayu Permatasari, Aty Widyawaruyanti, and Achmad Fuad

Article Category: Research Article

Article Number: 20190348

Published online: 14 Dec 2019

ABSTRACT

Background

Medicinal plants are known to perform many pharmacological actions due to their chemical metabolites, which include antiviral effects. Pr... Show More

- In vitro equivalence of generic and branded amoxicillin tablet by microbiological assay method

Primadi Avianto, Mahfudz, Suharjono, Isnaeni, and Christopher Paul Alderman

Article Category: Research Article

Article Number: 20190247

Published online: 11 Jan 2020

ABSTRACT

Background

Indonesian Ministry of Health advocate doctors, especially in government-owned healthcare facility, to prescribe generic drugs including... Show More

- Knowledge and attitude: two fundamental factors that determine patient compliance in antibiotic therapy

Liza Pristianty, Vivi Laily Kurniati, and Ika Ratna Hidayati

Article Category: Research Article

Article Number: 20190321

Published online: 12 Feb 2020

ABSTRACT

Background

With the development of infectious diseases, the use of antibiotics is increasing. Amoxicillin is a penicillin class of antibiotics that a... Show More

- Molecular docking study of sappan wood extract to inhibit PBP2A enzyme on methicillin-resistant Staphylococcus aureus (MRSA)

Marisca Evalina Gondokesumo and Ihsan Mulyadi Kurniawan

Article Category: Research Article

Article Number: 20190282

Published online: 18 Jan 2020

ABSTRACT

Background

PBP2a is a type of penicillin-binding proteins (PBPs) that cause resistivity in methicillin-resistant Staphylococcus

aureus (MRSA) from... Show More

- Effect of curcumin analogue synthetic product from cullilawan oil for the liver damage treatment in male mice (Mus musculus L.)

Imanuel Berly Delvis Kapelle, Wasmen Manalu, and Fensia Analda Souhoka

Article Category: Research Article

Article Number: 20190241

Published online: 23 Jan 2020

ABSTRACT

The active component in cullilawan oil can be synthesized into curcumin analogue product, which has pharmacological activity. The synthesis proce... Show More

- CASE REPORT

- A case report of generalized tetanus in a 42-year-old man with dental infection

Maria Ulfa and Nuril Auliya Husna 
Article Category: Case Report

Article Number: 20190243

Published online: 07 Dec 2019

ABSTRACT

Background

In the post-vaccination era, as it is today, generalized tetanus is a rare diagnosis, although mortality and morbidity continue to incre... Show More 


\title{
Synergistic anti-hepatitis C virus activity of Ruta angustifolia extract with NS3 protein inhibitor
}

\author{
${ }^{1}$ Department of Pharmacognosy and Phytochemistry, Faculty of Pharmacy, Airlangga University, Surabaya 60115, Indonesia, \\ E-mail: tutik-s-w@ff.unair.ac.id \\ ${ }^{2}$ Institute of Tropical Disease, Airlangga University, Surabaya 60115, Indonesia, E-mail: tutik-s-w@ff.unair.ac.id
}

\begin{abstract}
:
Background: Medicinal plants are known to perform many pharmacological actions due to their chemical metabolites, which include antiviral effects. Previously, the extract of Ruta angustifolia was shown to have potential anti-hepatitis $C$ virus (HCV) activity without any cytotoxicity, with a $50 \%$ inhibitory concentration of 3.0 $\mu \mathrm{g} / \mathrm{mL}$ and a $50 \%$ cytotoxicity concentration of $>100 \mu \mathrm{g} / \mathrm{mL}$. Furthermore, the combination of medicinal plants and current anti-HCV agents, such as a direct-acting antiviral agent, was shown to potentiate their overall effectiveness. In the course of this study, the ethanolic extract of R. angustifolia was evaluated for its anti-HCV effects; specifically, the mechanism of action on HCV NS3 and NS5A protease was investigated.

Methods: Analysis of the use of this extract in conjunction with current NS3 inhibitor drugs, simeprevir (SMV) and telaprevir (TVR), was performed. Anti-HCV activity was performed by in vitro culture of hepatocyte cells. The cells were infected and treated with various concentrations of the sample. HCV inhibition was calculated and CompuSyn software analysis was used to determine the synergistic effect of the combination.

Results: Results demonstrated that R. angustifolia extract inhibited the post-entry step and decreased the protein levels of HCV NS3 and NS5A. The combination of extract and SMV and TVR mediated a synergistic effect.

Conclusions: These findings suggest that combining $R$. angustifolia extract with current anti-HCV drugs should be considered when developing alternative and complementary anti-HCV medicines.
\end{abstract}

Keywords: Ruta angustifolia, simeprevir, synergistic, telaprevir

DOI: $10.1515 /$ jbcpp-2019-0348

Received: November 17, 2019; Accepted: November 18, 2019

\section{Introduction}

Medicinal plants are potential sources for finding new drugs. Metabolites of many plants have been reported to possess several biopharmacological effects, including antiviral activities; this includes inhibiting the activity of hepatitis C virus (HCV) [1]. Ruta angustifolia is a plant belonging to the Rutaceae family and has been used as traditional herbal remedy [2]. In Indonesia, it is known as a traditional herb for jaundice. In our previous study, a number of compounds exhibiting anti-HCV effects have been isolated from $\mathrm{R}$. angustifolia, including chalepin, arborinine, $\gamma$-fagarine, kokusagenin, and pseudane IX [3]. Here, strong evidence supports the combination of R. angustifolia extract and current anti-HCV drugs as warranted for the drug development of anti-HCV agents.

$\mathrm{HCV}$ infection is a global health problem that chronically infects more than 71 million people, putting them at risk for developing cirrhosis or liver cancer [4]. At this time, there is no vaccine available for preventing $\mathrm{HCV}$ infection. Although the most recent therapy being developed is a combination of direct-acting antivirals (DAAs), these include NS3 protease, NS5A protein, and NS5B RNA polymerase with a sustained virologic response (SVR) of $>90 \%$, especially in HCV genotype 1 patients. However, despite its efficacy, limits with this treatment remain problematic; the high cost is prohibitive to patient access. Furthermore, potential for drug resistance and side effects associated with long-term use have been observed [5]. Thus, the development of new anti-HCV agents and/or combination therapies is imperative to improve the overall efficacy of HCV treatment.

The goal of HCV treatment is curative and defined as achieving undetectable HCV RNA concentrations within 12 weeks (i.e. SVR12) or 24 weeks (i.e. SVR24) of treatment [4]. Anti-HCV agents can be divided into two classes: DAAs (discussed above) that directly target viral NS3 protease, NS5B polymerase, or NS5A protein and host-targeting antivirals, such as cyclophilin inhibitors [6]. Currently, the standard therapies for HCV infection include interferon (IFN)- $\alpha$ and other alternative IFN-free treatment regimens that use two or three types of DAAs in combination. 
The combination of anti-HCV compounds is often shown to provide a greater reduction in HCV RNA levels compared to the use of each agent singularly. For example, the inhibitory effect of IFN (concentration of 5 IU) on $\mathrm{HCV}$ is $55 \%$. With the addition of glycyrrhizin (a plant extract of Glycyrrhiza glabra at a concentration of 10 $\mu \mathrm{g} / \mathrm{mL}$ ), the inhibitory antiviral effect of IFN increased to $95 \%$. In addition, extracts from the Acacia confusa plant, when combined with IFN, telaprevir (TVR), and 2'-C-methylcytidine, showed a synergistic effect with a combination index (CI) of <1 [7], [8]. These data support the potential for increased efficacies when developing combination therapies between natural compounds and anti-HCV agents, including DAAs. This study determined the antiviral effect of $R$. angustifolia extract when combined with simeprevir (SMV) and TVR.

\section{Materials and methods}

\section{Collection and extraction}

The leaves of R. angustifolia used were from Lembang, West Java, Indonesia. The sample was identified by expert botanical researchers in Purwodadi, Indonesia. The leaf samples were then dried at room temperature, ground to powder, and extracted via maceration with $96 \%$ ethanol for a total of 3 days. The collected filtrate was then concentrated using a rotary evaporator until the desired thickness was obtained.

\section{Cell and virus preparation}

Hepatocyte cells (Huh7it) were cultivated in $10 \mathrm{~cm}$ dish with $10 \mathrm{~mL}$ Dulbecco's modified Eagle's medium (Wako Chemicals) and supplemented with fetal bovine serum (Biowest, Inc.), nonessential amino acids (Invitrogen), $100 \mathrm{IU} / \mathrm{mL}$ penicillin, and $100 \mu \mathrm{g} / \mathrm{mL}$ streptomycin (Invitrogen). Cells were then grown at $37{ }^{\circ} \mathrm{C}$ in a $5 \% \mathrm{CO}_{2}$ incubator. HCV (J6-JFH1 strain) was propagated as described previously [3], [9] and inoculated into Huh7it cells, which were then cultured for 2 days. After culture, the supernatants were collected, and the viral titers were determined.

\section{Sample preparation for anti-HCV activity}

Ruta angustifolia extract was dissolved in dimethylsulfoxide (DMSO) to make a stock solution at a concentration of $100 \mu \mathrm{g} / \mathrm{mL}$. SMV and TVR, both made in stock at a concentration of $1000 \mathrm{nM}$, were the DAAs tested. All stock solutions were stored at $-30{ }^{\circ} \mathrm{C}$ until used.

\section{Analysis of anti-HCV activity}

Huh7it cells were seeded in 48 -well plates at a density of $5.4 \times 10^{4}$ cells per well. HCV was mixed with a serial dilution of the extract and inoculated into the cells at a multiplication of infection of 0.5 focus-forming units/cell. After $2 \mathrm{~h}$, the cells were washed with medium to remove any residual virus and then further incubated in medium containing the antiviral compounds. The cultured supernatants were collected 2 days after infection and then titrated to determine the virus infectivity [9]. Virus and cells treated with medium containing $0.1 \%$ DMSO served as the control. The percent inhibition of virus infectivity was calculated for each sample by comparing the infectivity of test samples to that of control using SPSS probit analysis to determine the $50 \%$ inhibitory concentration $\left(\mathrm{IC}_{50}\right)$ values.

\section{Mode of action analysis}

Mode of action analysis was evaluated by in vitro culture cells of HCV. Ruta angustifolia extract was analyzed by a three-series model in parallel. First, the extract was treated only during inoculation ( $2 \mathrm{~h}$ ), the remaining virus was discarded, and the extract was refed into the medium until $46 \mathrm{~h}$ incubation. Second, the culture was treated with extract only after inoculation for $46 \mathrm{~h}$. Third, the culture was treated with extract in both entry and post-entry steps. 


\section{Immunoblotting analysis}

Treated Huh7it cells were lysed with radioimmunoprecipitation assay buffer and the amount of protein was calculated. Equal amounts of protein were separated in sodium dodecyl sulfate-polyacrylamide gel electrophoresis gels and transferred onto polyvinylidene difluoride membrane (Millipore, Bedford, MA, USA). First antibody HCV NS3-specific mouse monoclonal antibody (clone H23; Abcam, Cambridge, MA, USA) and glyceraldehyde-3-phosphate dehydrogenase antibody (MBL) were incubated for $1 \mathrm{~h}$, and phosphate-buffered saline- $0.05 \%$ Tween was used for membrane washing. Second antibody horseradish peroxidase-conjugated goat anti-mouse immunoglobulin (MBL) was incubated for $1 \mathrm{~h}$ and the respective protein was visualized using Clarity Western ECL substrate (Bio-Rad). Skim milk (5\%) was added to block the nonspecific binding for $60 \mathrm{~min}$ incubation. Chemiluminescence was detected using ImageQuant LAS 4000 (GE Healthcare).

\section{Combination treatment of $R$. angustifolia extract and anti-HCV drugs}

The effects of combination drug treatment were tested by adding R. angustifolia extract to anti-HCV DAA drugs, SMV (Toronto Research Chemical) and TVR (Adooq Bioscience), an HCV NS3 protein inhibitor). Three series of analyses were conducted simultaneously: (1) R. angustifolia extract alone, (2) each of the anti-HCV drugs alone, and (3) a mixture of $R$. angustifolia extract and each anti-HCV drug (1:100 ratio for the combination with SMV and 1:200 for the combination with TVR). The percent inhibition of virus infectivity for each sample was then calculated as described in Section 2.4. CompuSyn software was used to calculate the CI to determine whether the drug combination exerted an additive, synergistic, or antagonistic antiviral effect [10], [11], [12].

\section{Results}

It is known that $R$. angustifolia extract possesses strong antiviral activity against $\mathrm{HCV}$, with an $\mathrm{IC}_{50}$ value of 3.0 $\mu \mathrm{g} / \mathrm{mL}$ and a $50 \%$ cytotoxicity concentration of $>100 \mu \mathrm{g} / \mathrm{mL}$. It was postulated that the potency of $R$. angustifolia extract may increase if combined with other anti-HCV drugs. Therefore, the primary purpose of this study was to further analyze the anti-HCV effects of $R$. angustifolia extract in combination with existing anti-HCV agents, such as SMV and TVR.

Mode of action analysis found that R. angustifolia extract inhibited HCV dominantly in the post-entry step (Figure 1B). Further analysis by immunoblotting demonstrated an inhibition effect of R. angustifolia extract on HCV NS3 and NS5A protein. The result showed that $R$. angustifolia extract suppressed HCV protein NS3 and NS5A in culture cells (Figure 1C and D). 
A

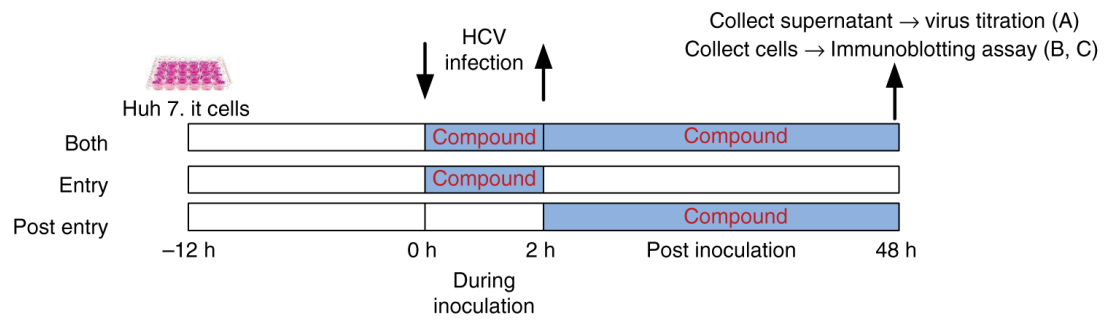

B

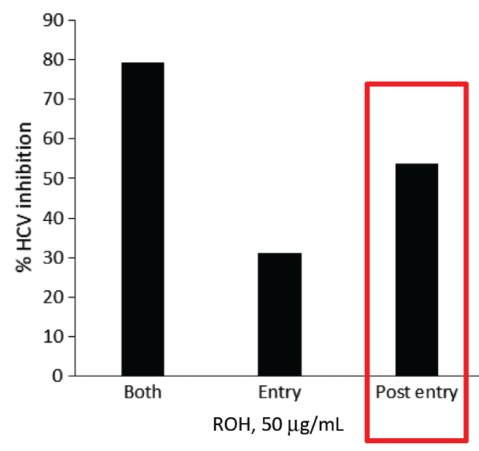

D

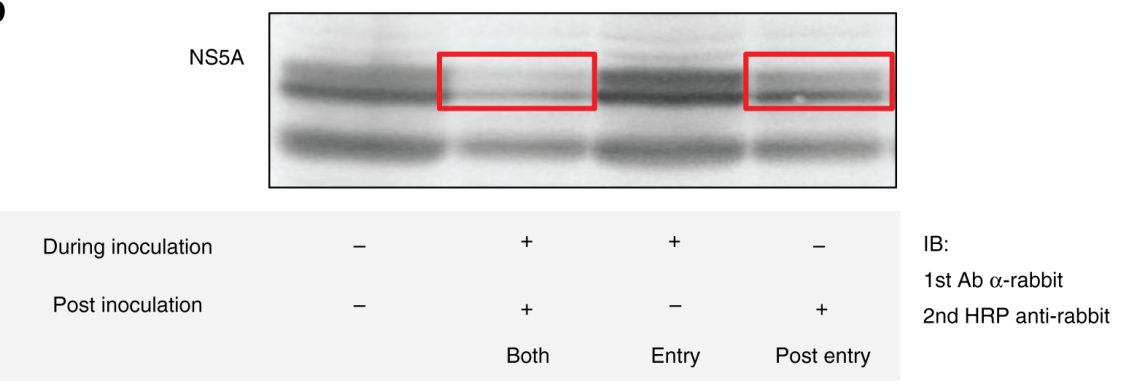

C

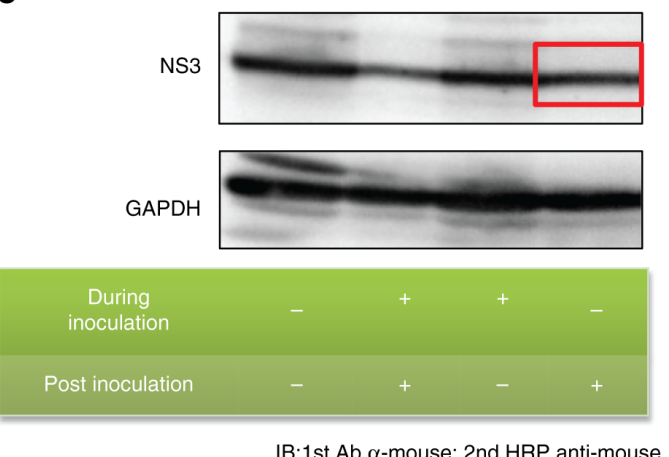

IB:1st Ab $\alpha$-mouse; 2nd HRP anti-mouse

Figure 1: Ruta angustifolia extract possesses strong inhibition in the post-entry step against HCV.

(A) Scheme of mode of action analysis. (B) Inhibition in the post-entry step is higher than that in the entry step. It decreases the NS3 (C) and NS5A (D) protein level.

The combination treatment of $R$. angustifolia extract and SMV revealed a higher inhibition of HCV compared to treatment with either of the drugs alone. The $\mathrm{IC}_{50}$ of SMV used singularly was $43.84 \pm 0.96 \mathrm{nM}$, whereas the combination treatment improved the inhibitory effect of SMV to an $\mathrm{IC}_{50}$ value of $19.70 \pm 0.28 \mathrm{nM}$. The results using CompuSyn software determined a CI value of $\mathrm{ED}_{50}=0.883(<1)$; Table 1, Figure 2), thus showing that this combination treatment has a synergistic effect on the inhibition of HCV [10]. Combination was also performed with TVR and obtained the higher HCV inhibition compare to the TVR single drug alone (Figure 3).

Table 1: $\mathrm{IC}_{50}$ of single administration and combination of extract and SMV and TVR.

\begin{tabular}{lr}
\hline Samples & ${\text { Anti-HCV activity }\left(\mathbf{I C}_{50}\right), \mathbf{n M}}^{\text {SMV }}$ \\
\hline TVR & $43.84 \pm 0.96$ \\
Combination extract and SMV & $10.48 \pm 0.11$ \\
Combination extract and TVR & $19.70 \pm 0.28$ \\
\end{tabular}

Data are mean \pm SE from three independent experiments. 
A

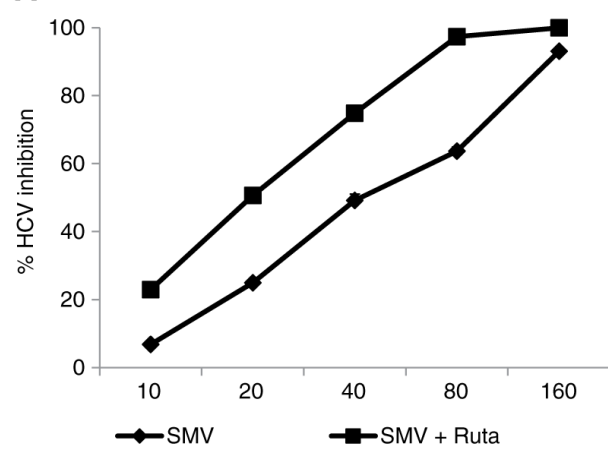

B

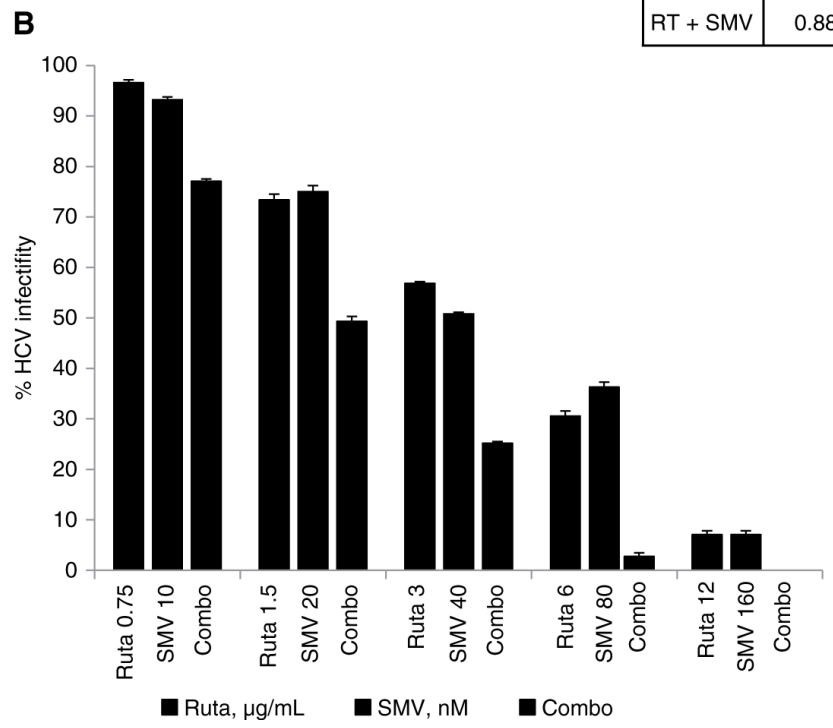

C

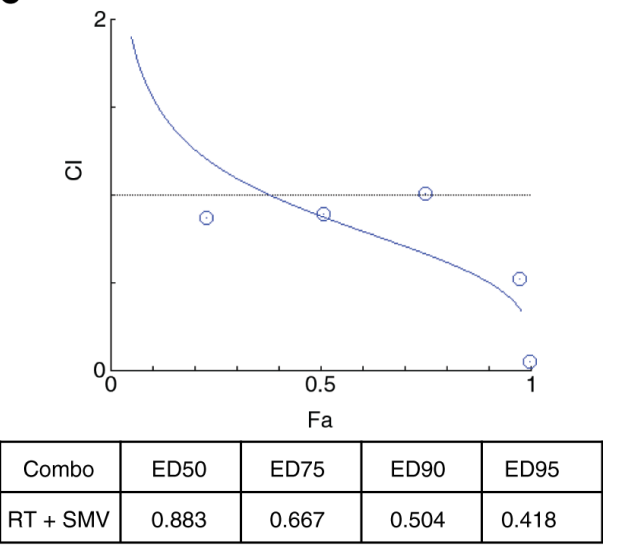

Figure 2: Ruta angustifolia extract in enhanced anti-HCV activity of SMV.

Huh7it cells seeded in 48-well plates were infected with HCV and treated with R. angustifolia extract. Culture supernatant was collected for virus titration. The percentage HCV inhibition was calculated and compared to control. The combination treatment increased anti-HCV activities. Serial dilution of the concentration of extract and SMV was inoculated according to the method of Chou and Talalay. The addition of R. angustifolia extract increased HCV inhibition compare to the single treatment of SMV in doses dependent manner (A). Ruta angustifolia extract in combination with SMV decreased HCV infectivity more than the treatment of either drug alone (B). CompuSyn analysis of the drug combination treatment demonstrates a synergistic effect $(\mathrm{CI}<1.0)(\mathrm{C})$. Data are mean \pm standard error $(\mathrm{SE})$ from three independent experiments. 
A

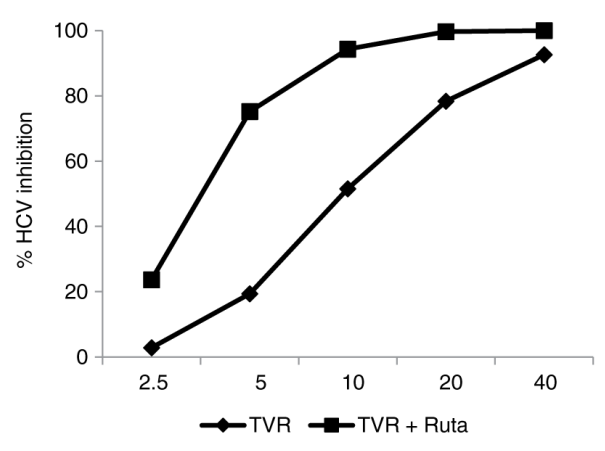

B

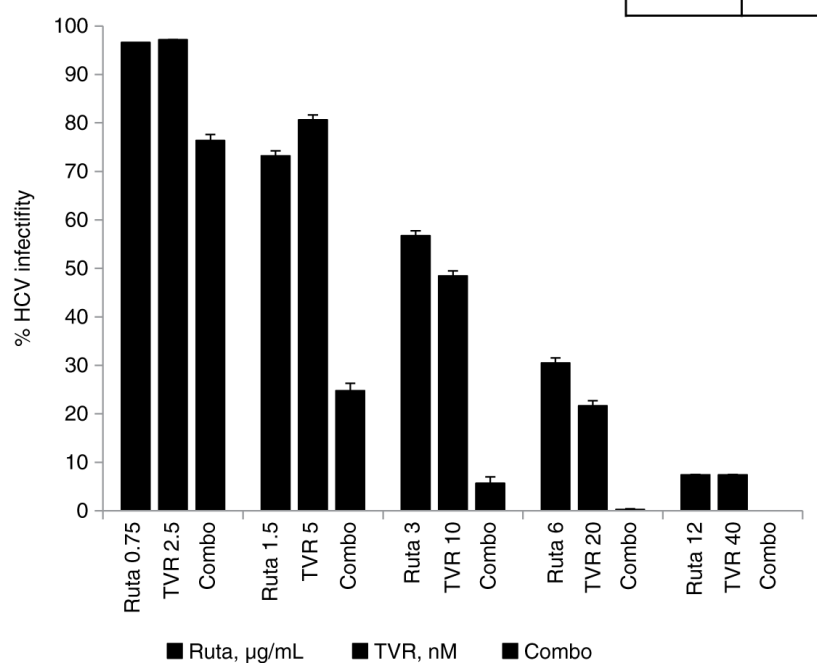

C

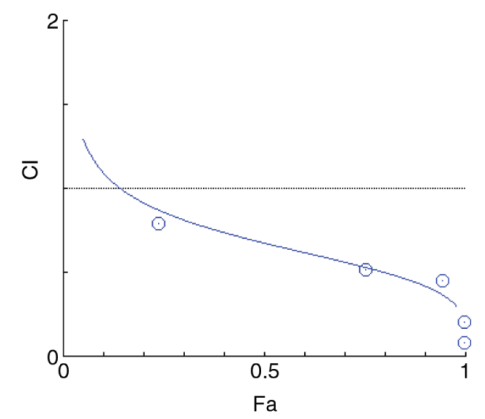

\begin{tabular}{|c|c|c|c|c|}
\hline Combo & ED50 & ED75 & ED90 & ED95 \\
\hline RT + TVR & 0.677 & 0.533 & 0.420 & 0.358 \\
\hline
\end{tabular}

Figure 3: Ruta angustifolia extract showed to increase anti-HCV activity of TVR.

Huh7it cells seeded in 48-well plates were infected with HCV and treated with R. angustifolia extract. Culture supernatant was collected for virus titration. The percentage HCV inhibition was calculated and compared to control. The combination treatment increased anti-HCV activities. Serial dilution of the concentration of extract and TVR was inoculated according to the method of Chou and Talalay. The addition of R. angustifolia extract increased HCV inhibition compare to the single treatment of TVR in doses dependent manner (A). Ruta angustifolia extract in combination with TVR decreased HCV infectivity more than the treatment of either drug alone (B). CompuSyn analysis of the drug combination treatment demonstrates a synergistic effect $(\mathrm{CI}<1.0)(\mathrm{C})$. Data are mean $\pm \mathrm{SE}$ from three independent experiments.

\section{Discussion}

The chemical metabolites contained in medicinal plants are known to provide important pharmacological uses. Thus, the continued discovery of naturally produced compounds has been important in the development of new drugs. Moreover, societies that lack access or the financial means to purchase more modern, synthetic drugs use natural compounds as do the people who wish to minimize the potential side effects from synthetic drugs.

Natural compounds known to possess antiviral effects against HCV include the flavonoid compounds quercetin, naringenin, and catechin, which collectively inhibit $\mathrm{HCV}$, thus demonstrating significant potential in reducing NS3 and NS5A protein levels in HCV-infected patients [13], [14]. Similarly, circumdatin G (an alkaloid compound) has been shown to protect patients from fungus-mediated anti-HCV activity [15]. Polyphenol compounds, such as ethyl gallate, catechin gallate, delphenidin, saikosaponin b2, and grosheimol, likewise have been shown to inhibit HCV in the initial stages of infection [16].

The purpose of HCV therapy is to eradicate the virus in a patient, the success of which is indicated by its SVR. Combination drugs are the current modality used to treat HCV; however, their efficacy is lacking. The drug treatment combination of IFN and RBV achieves only 50\% SVR after 24 weeks. Furthermore, this treatment may cause serious side effects. The most currently used HCV treatment regimen involves using an IFN-free combination of two to three DAAs - NS3/4A protease, NS5A, and NS5B polymerase inhibitors. This treatment approach has better success compared to treatment using IFN alone (SVR > 90\%) [4]. However, viral resistance and potentially undesirable side effects are still seen. Moreover, these antiviral synthetic drugs are 
expensive, making them inaccessible to patients with limited income. The differential responses of various $\mathrm{HCV}$ genotypes to these treatments underscore the need to find new and less expensive anti-cofactor enzymes so that it will suppress the replication process of HCV [17].

In general, the HCV life cycle process consists of receptor binding, fusion, translation, replication, virion assembly, and released virion. Th entry step is defined as the stage consisting of receptor binding through translation, whereas the stage of replication through virion release constitutes the post-entry stage. Ruta angustifolia extract has been shown to inhibit HCV in the post-entry step through its inhibition of NS3 and NS5A (see Figure 1).

SMV and TVR are DAAs; their direct mechanism of action as NS3/4A protease inhibitors is to disrupt the work of the protease and cofactor enzymes and thereby suppress the replication process of HCV [17].

NS3/4A inhibitors are conventionally grouped into two classes. The first class (first generation) are linear peptidomimetics that incorporate a reactive electrophilic ketoamide at the cleavage site; this then targets the catalytic Ser139 of the active site of the enzyme via a fully reversible mechanism. Examples of this class include TVR and boceprevir. The second class (second generation) includes competitive, reversible, macrocyclic, noncovalent inhibitors. Macrocycles are useful to improve affinity and selectivity for protein targets while preserving the sufficient bioavailability characteristics of small molecules. Belonging to this class is SMV [18], which has a macrocyclic structure; it is thought to have an advantage over first-generation protease inhibitors, and their linear structures, in terms of binding affinity and specificity for NS3 protease [19].

We demonstrated in this study that the combinatory addition of $R$. angustifolia extract increased the antiHCV activities of SMV and TVR. Moreover, the extract exerted a synergistic effect with CI values of $<1$. The extract alone of R. angustifolia suppressed HCV production and reduced the HCV NS3 and NS5A protein level. These results suggest that combinations of SMV and TVR with $R$. angustifolia extract may good candidates to consider as combination.

\section{Conclusions}

The combination of R. angustifolia extract and the current anti-HCV drugs was shown to enhance the overall antiviral effectiveness by giving an additive synergistic effect. Therefore, the addition of $R$. angustifolia extract to existing drug combinations should be considered in the development of alternative and complementary anti-HCV treatment.

\section{Acknowledgments}

The authors are sincerely grateful to Prof. Hak Hotta and Dr. Chie Aoki Utsubo for providing HCV and hepatocyte cells.

Author contributions: All authors have accepted responsibility for the entire content of this manuscript and approved its submission.

Research funding: None declared.

Competing interests: The authors state no conflict of interest.

\section{References}

[1] Wahyuni TS, Utsubo CA, Hotta H. Promising anti-hepatitis C virus compounds from natural resources. Nat Prod Commun 2016;11:1193200.

[2] Pollio A, De Natale A, Appetiti E, Aliotta G, Touwaide A. Continuity and change in the Mediterranean medical tradition: Ruta spp. (rutaceae) in Hippocratic medicine and present practices. J Ethnopharmacol 2008;116:469-82.

[3] Wahyuni TS, Widyawaruyanti A, Lusida MI, Fuad A, Soetjipto, Fuchino H, et al. Inhibition of hepatitis C virus replication by chalepin and pseudane IX isolated from Ruta angustifolia leaves. Fitoterapia 2014;99:276-83.

[4] Pawlotsky JM, Negro F, Aghemo A, Berenguer M, Dalgard O, Dusheiko G, et al. EASL recommendations on treatment of hepatitis C 2018. ] Hepatol 2018;69:461-511.

[5] Manns MP, Foster GR, Rockstroh JK, Zeuzem S, Zoulim F, Houghton M. The way forward in HCV treatment - finding the right path. Nat Rev Drug Discov 2007;6:991-1000. 
[6] Conzalez-Crande R, Jimenez-Perez M, Conzalez Arjona C, Mostazo Torres ]. New approaches in the treatment of hepatitis C. World ] Gastroenterol 2016;22:1421-32.

[7] Ashfaq UA, Masoud MS, Nawaz Z, Riazuddin S. Clycyrrhizin as antiviral agent against hepatitis C virus. ] TransI Med 2011;9:112.

[8] Lee JC, Chen WC, Wu SF, Tseng CK, Chiou CY, Chang FR, et al. Anti-hepatitis C virus activity of Acacia confusa extract via suppressing cyclooxygenase-2. Antiviral Res 2011;89:35-42.

[9] Wahyuni TS, Tumewu L, Permanasari AA, Apriani E, Adianti M, Rahman A, et al. Antiviral activities of Indonesian medicinal plants in the East Java region against hepatitis C virus. Virol ] 2013;10:259.

[10] Chou TC. Theoretical basis, experimental design, and computerized simulation of synergism and antagonism in drug combination studies. Pharmacol Rev 2006;58:621-81.

[11] Tallarida R]. An overview of drug combination analysis with isobolograms. ] Pharmacol Exp Ther 2006;319:1-7.

[12] Tallarida R]. Drug combinations: tests and analysis with isoboles. Curr Prot Pharmacol 2016;72:9.19.1-19.

[13] Ciesek S, von Hahn T, Colpitts CC, Schang LM, Friesland M, Steinmann ], et al. The green tea polyphenol, epigallocatechin-3-gallate, inhibits hepatitis C virus entry. Hepatology 2011;54:1947-55.

[14] Khachatoorian R, Arumugaswami V, Raychaudhuri S, Yeh CK, Maloney EM, Wang ], et al. Divergent antiviral effects of bioflavonoids on the hepatitis C virus life cycle. Virology 2012;433:346-55.

[15] Dai ], Carte BK, Sidebottom P], Sek Yew AL, Ng S, Huang Y, et al. Circumdatin G, a new alkaloid from the fungus Aspergillus ochraceus. ] Nat Prod 2001;64:125-6.

[16] Elsebai MF, Koutsoudakis G, Saludes V, Perez-Vilaro G, Turpeinen A, Mattila S, et al. Pan-genotypic hepatitis C virus inhibition by natural products derived from the wild Egyptian artichoke. J Virol 2016;90:1918-30.

[17] Tamori A, Enomoto M, Kawada N. Recent advances in antiviral therapy for chronic hepatitis C. Mediat Inflamm 2016;2016:11.

[18] Izquierdo L, Helle F, Francois C, Castelain S, Duverlie G, Brochot E. Simeprevir for the treatment of hepatitis C virus infection. Pharmgenomics Pers Med 2014;7:241-9.

[19] Sarrazin C, Zeuzem S. Resistance to direct antiviral agents in patients with hepatitis C virus infection. Gastroenterology 2010;138:447-62. 
Q

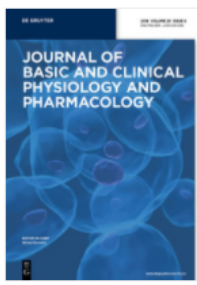

\section{Journal of Basic and Clinical}

$€ 99.00$ Physiology and Pharmacology

Online

ADD TO CART

INSTITUTIONAL PRICING SEARCH

Search within Journa Q 


\section{Journal of Basic and Clinical Physiology and Pharmacology}

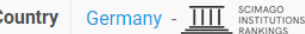

$\begin{array}{r}\text { Subject Area and } \\ \text { Category }\end{array}$
$\begin{gathered}\text { Biochemistry, Genetics and Molecular Biology } \\ \text { Physiology }\end{gathered}$

Medicine

Medicine (miscellaneous)

31

H Index

Pharmacology, Toxicology and Pharmaceutics Drug Discovery

Publisher Walter de Gruyter GmbH

Publication type Journals

ISSN 21910286,07926855

Coverage $\quad 1985-1988,1990-2020$

Scope The Journal of Basic and Clinical Physiology and Pharmacology (JBCPP) is a peer-reviewed bi-monthly published journal in experimental medicine, JBCPP publishes novel research in the physiological and pharmacological sciences, including brain research; cardiovascular-pulmonary interactions; exercise; thermal control; haematology; immune response; inflammation; metabolism; oxidative stress; and phytotherapy. As the borders between physiology, pharmacology and biochemistry become increasingly blurred, we also welcome papers using cutting-edge techniques in cellular and/or molecular biology to link descriptive or behavioral studies with cellular and molecular mechanisms underlying the integrative processes. Topics: Behavior and Neuroprotection, Reproduction, Genotoxicity and Cytotoxicity, Vascular Conditions, Cardiovascular Function, Cardiovascular-Pulmonary Interactions, Oxidative Stress, Metabolism, Immune Response, Hematological Profile, Inflammation, Infection, Phytotherapy.
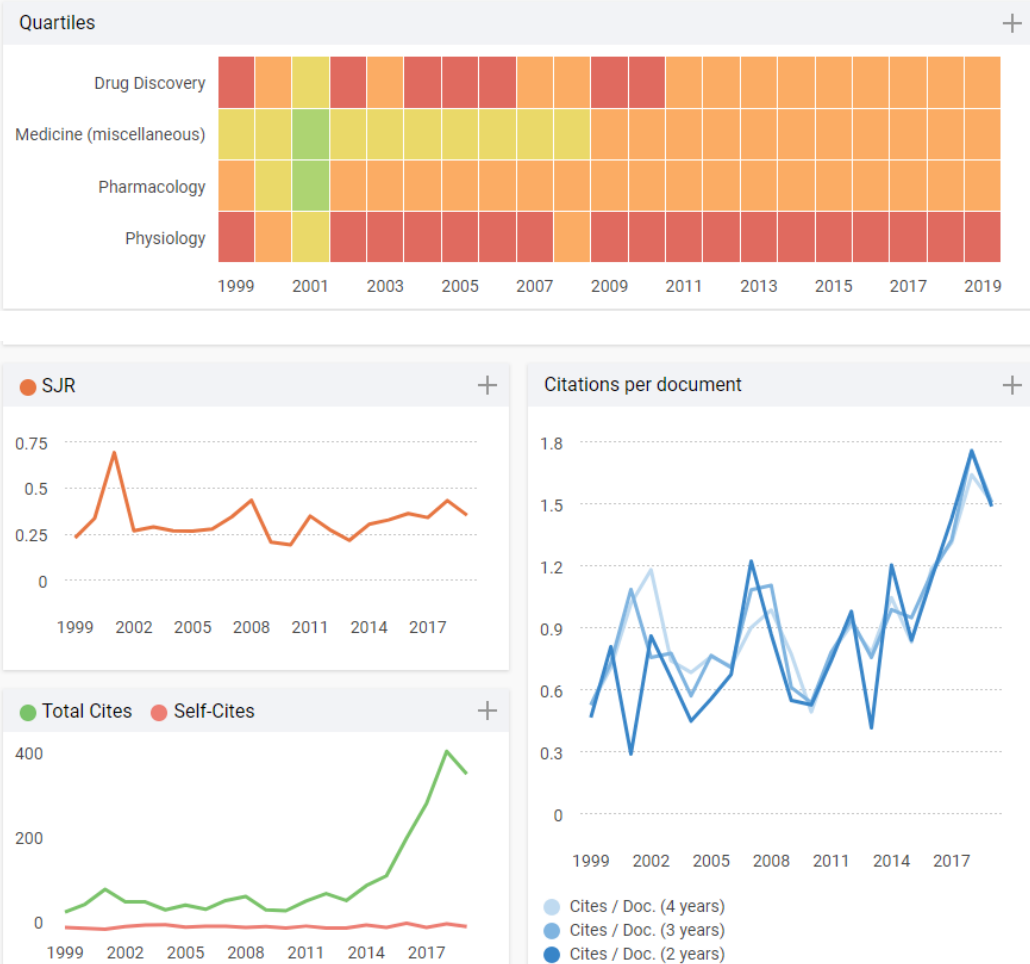

Citations per document

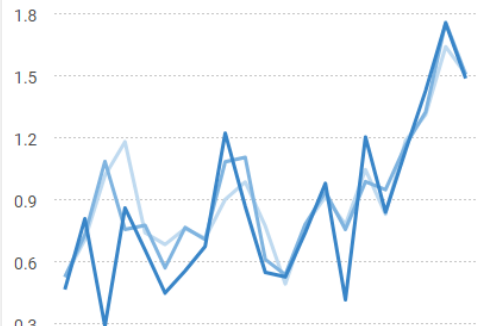

0.3

Cites / Doc. (4 years)

Cites / Doc. (3 years)

Cites / Doc. (2 years)

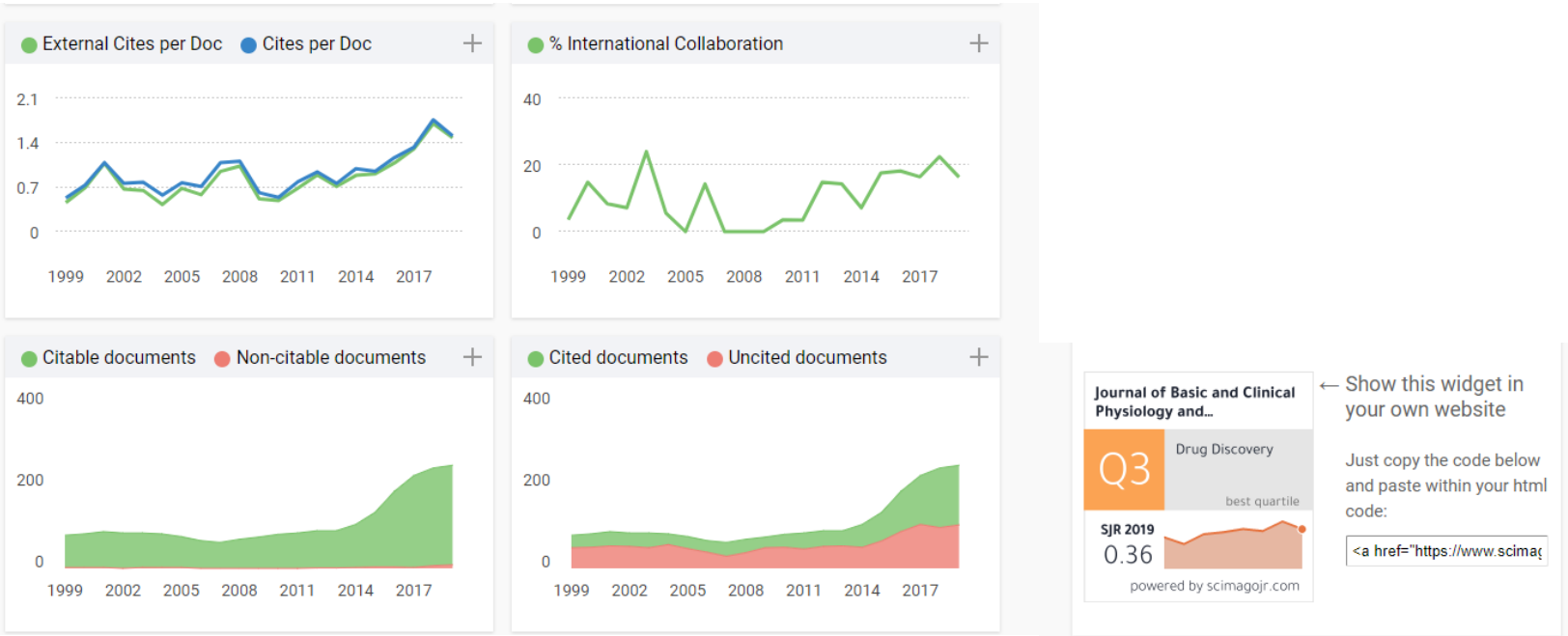

